\title{
Penerapan Asas Lex Specialis Derogat Legi Generalis dan Penyelesaian Sengketa Ekonomi dalam Undang-Undang Perbankan Syariah di Indonesia
}

\author{
Fikri \\ (Jurusan Syariah dan Ekonomi Islam STAIN Parepare, Jln. Amal Bakti No.8, Email: \\ fikristainpare@gmail.com) \\ Budiman \\ (Jurusan Syariah dan Ekonomi Islam STAIN Parepare, Jln. Amal Bakti No.8, Email: \\ Sulaemanbudiman@gmail.com)
}

\begin{abstract}
Abstrak:
Tulisan ini mengkaji Undang-Undang Republik Indonesia No. 23/2004 tentang Perubahan atas Undang-Undang Republik Indonesia No. 10/1998 tentang Bank Indonesia, yang berlaku umum. Sedangkan Undang-Undang Republik Indonesia No. 21/2008 tentang Perbankan Syariah, berlaku khusus. Penerapan asas lex specialis derogat legi generali menegaskan bahwa Undang-Undang Republik Indonesia No. 21/2008 memiliki kedudukan lebih kuat dibandingkan UndangUndang Republik Indonesia No. 23/2004 yang berlaku umum. Keberlakuan Undang-Undang Republik Indonesia Nomor 21/2008 mengokohkan eksistensi perbankan syariah untuk leluasa menjalankan aktivitas dan produk-produknya. Di samping itu, apabila merujuk kepada Undang-Undang Republik Indonesia No. 30/1999, maka penyelesaian sengketa perbankan syariah dapat ditempuh melalui dua cara yaitu, pengadilan negeri dan badan arbitrase. Namun setelah berlakunya Undang-Undang Republik Indonesia No. 21/2008 Pasal 55, dengan jelas disebutkan bahwa pengadilan yang berwenang melaksanakan putusan Badan Arbitrase Syariah Nasional (Basyarnas) dan menyelesaikan sengketa perbankan syariah adalah pengadilan agama.
\end{abstract}

kata Kunci:

Undang-undang, Penyelesaian Sengketa Ekonomi Syariah, Arbitrase, Pengadilan Agama

\author{
Abstract: \\ al-1hkâm Vol.12 No.1 Juni 2017 \\ DOI 10.19105/al-ihkam.v12i1.1200
}


This paper reviews the Act of the Republic of Indonesia Number 23/2004 regarding Amendment to the Act Number 10/1998 concerning Indonesia Bank, which is in effect generally. On the other hand, the Act number 21/2008 regarding sharia banking applies more specifically. The application of lex specialis derogat legi generali principle confirms that the Law of the Republic of Indonesia Number $21 / 2008$ has a stronger position than the Law Number $23 / 2004$, which is generally in effect. The enforcement of the Law of the Republic of Indonesia Number 21/2008 affirms the existence of sharia banking to freely run its activities and products. In addition, when referring to the Law of the Republic of Indonesia Number 30/1999, the resolution of Islamic banking disputes can be done through two ways, namely, the district court and the arbitration body. However, after the Law of the Republic of Indonesia Number 21/2008, Article 55 comes into effect, it is clearly stated that the court authorized to enforce the decision of the National Sharia Arbitration Board (Basyarnas) and settle the disputes over sharia banking is a religious court.

\section{Key Words:}

Law, Sharia Economic Dispute Resolution, Arbitration, Religious Court

\section{Pendahuluan}

Sebelum kedatangan Belanda berkuasa di Indonesia, telah berkembang dalam masyarakat dengan sistem transaksi yang sangat kuat yakni perbankan Islam. Sistem perbankan dilaksanakan oleh masyarakat dengan penuh kesadaran dan ketaatan berdasarkan dengan hukum Islam. Berlahan-lahan tetapi pasti, Pemerintah Belanda melakukan perubahan dengan mengganti seluruh sistem transaksi Islam menjadi sistem konvensional, termasuk sistem perbankan. Akibatnya, kenyataan dalam masyarakat telah meninggalkan sistem perbankan Islam berganti menjadi sistem perbankan konvensional.

Bank-bank syariah mulai bangkit dan memiliki gairah ditandai dengan lahirnya UU No. 21/2008 tentang Perbankan Syariah. Bank-bank syariah telah menunjukkan trend perkembangan yang positif sehingga dapat memainkan peranan penting dalam memobilisasi, mengalokasi dan memanfaatkan sumber daya dengan 
lebih baik. Salah satu faktor pendukung yang menunjang trend positif itu adalah pembagian hasil dalam pembiayaan yang menggunakan konsep profit sharing dan revenue sharing dengan akad mudharabah, meski pada awalnya konsep ini tidak begitu luas dimengerti oleh masyarakat. ${ }^{1}$

Diperlukan pembentukan citra baru perbankan syariah nasional yang bersifat inklusif dan universal, pemetaan pasar secara lebih akurat, pengembangan produk yang lebih beragam, peningkatan layanan, serta strategi komunikasi baru yang memposisikan perbankan syariah lebih dari sekedar bank. Program pencitraan baru perbankan syariah meliputi aspek positioning, differentiation, dan branding. Positioning baru bank syariah sebagai perbankan yang saling menguntungkan kedua belah pihak, aspek diferensiasi dengan keunggulan kompetitif dengan produk dan skema yang beragam, transparan, kompeten dalam keuangan dan beretika, teknologi informasi yang selalu up-date dan user friendly, serta adanya ahli investasi keuangan syariah yang memadai. ${ }^{2}$

Bank syariah secara umum dituangkan dalam prinsip ekonomi syariah sebagaimana dikemukakan oleh Ahmad Supriadi;

"Islamic economics emphasizes justice, welfare and honesty. System of Islamic economic has merits that should be the way for Muslims to give well-being and becoming a necessity. The economic sharia is Islamic economics in use as a way for Muslims to complete their economic needs. It is Refers to the meaning of the word sharia which means wide way. As a fair economy and provide for the public welfare, it is feasible to make our way through the economy as Islam set principles." 3

(Ekonomi Islam menekankan keadilan, kesejahteraan dan kejujuran. Sistem ekonomi Islam memiliki kelebihan yang seharusnya menjadi jalan bagi umat Islam untuk memberi kesejahteraan dan menjadi kebutuhan. Syariah ekonomi adalah ekonomi Islam yang digunakan

\footnotetext{
1 Nunung Rodliyah, “Arbitrase Syariah sebagai Alternatif Penyelesaian Sengketa Lembaga Perbankan Syariah serta Kekuatan dan Kelemahan dalam Penerapan di Indonesia", The 16 th Annual Internasional Conference on Islamic Studies, AICIS 2016, IAIN Raden Intan Lampung, (November, 2016), 157-158.

2 Bambang Iswanto, "Peran Bank Indonesia, Dewan Syariah Nasional, Badan Wakaf Indonesia dan Baznas dalam Pengembangan Produk Hukum Ekonomi Islam di Indonesia", Iqtishadia, Jurnal Kajian Ekonomi Dan Bisnis Islam, Vol. 9, No. 2 (Juli, 2016), 421-439.

3 Ahmad Supriadi, "Implementation Of Islamic Economic about Mortgages,"Qijis, Qudus International Journal Of Islamic Studies, Vol.1, Issue 2, (Agust, 2014), 122.
} 
sebagai cara bagi umat Islam untuk melengkapi kebutuhan ekonomi mereka. Hal ini mengacu pada arti kata syariah yang berarti jalan yang lebar. Sebagai ekonomi yang adil dan memberikan kesejahteraan bagi masyarakat, adalah layak untuk melewati ekonomi karena Islam menetapkan prinsip).

Berkaitan dengan prinsip ekonomi syariah itu tidak lepas dari keadilan, menghapus riba dan mewajibkan zakat, ${ }^{4}$ sehingga eksitensi bank syariah yang tersebar di seluruh Indonesia tumbuh dengan pesat, termasuk di Kota Parepare yang saat ini terdapat tiga bank syariah antara lain Bank Muamalat, Bank Syariah Mandiri (BSM) dan BNI Syariah. Bank syariah di Kota Parepare memiliki daya saing yang lebih kuat dibanding dengan bank konvensional. Oleh karena itu, hakim di Pengadilan Agama Parepare harus mempersiapkan diri dalam meningkatkan kompetensinya menyelesaikan sengketa perbankan syariah.

Berdasarkan latar belakang itu, maka permasalahan dalam penelitian ini adalah bagaimana penerapan asas lex specialis derogat legi generalis dalam undang-undang perbankan syariah di Indonesia; bagaimana prosedur penyelesaian sengketa perbankan syariah.

Penelitian ini merupakan penelitian kualitatif (qualitative research) dengan penelitian lapangan (field research) dengan metode deskriptif-analitis kritis yang dilakukan untuk menjelaskan penerapan asas lex specialis derogat legi generalis dalam undang-undang perbankan syariah di Indonesia dan prosedur penyelesaian sengketa perbankan syariah. Lokasi penelitian dilakukan di Pengadilan Agama dan Bank Muamalat Parepare. Analisis konsepsi penerapan asas lex specialis derogat legi generalis dalam undang-undang perbankan syariah di Indonesia dan prosedur penyelesaian sengketa perbankan syariah dikaji dengan menggunakan pendekatan, yaitu; (1) pendekatan yuridis formal, (2) pendekatan sosiologis (3) pendekatan filosofis yakni mendekati nilai-nilai filosofis terhadap pelaksanaan hukum Islam $^{5}$ dalam lembaga-lembaga penegak hukum.

4 Karimah Khasanah, "Hukum Ekonomi Syariah, Indeks Pembangunan Manusia dan Kapitalisme Global”, Al-Manahij, Jurnal Kajian Hukum Islam, Vol. IX, No.2, (Desember, 2015), 321.

5diungkapkan Syaltut, upaya mengembangkan pemahaman terhadap permasalahan hukum terkait dengan perubahan sosial sehingga hukum Islam tampak dinamis dalam menyikapi permasalahan kontemporer yang disebabkan perkembangan 


\section{Penerapan Asas Lex Specialis Derogat Legi Generalis dalam Undang-undang Perbankan Syariah di Indonesia}

Kehadiran hukum perbankan dalam khasanah sistem hukum Indonesia merupakan suatu conditio sinequa nan, seiring dengan berkembang dan pesatnya bisnis perbankan dalam sistem perekonomian nasional Indonesia. Pesatnya perkembangan bisnis perbankan telah diproteksi dengan lahirnya UU No. 7/1992 tentang Perbankan sebagai pengganti UU No. 14/1967 tentang Pokok Perbankan, kemudian disempurnakan dengan UU No. 10/1998. ${ }^{6}$

Merujuk pada UU No. 10/1998 tersebut, sistem perbankan syariah dikembangkan dengan tujuan sebagai berikut: (1) Memenuhi kebutuhan jasa perbankan bagi masyarakat yang tidak menerima konsep bunga. (2) Membuka peluang pembiayaan bagi pengembangan usaha berdasarkan prinsip kemitraan, sehingga konsep yang diterapkan adalah mutual investor relationship. (3) Memenuhi kebutuhan akan produk dan jasa perbankan yang memiliki beberapa keunggulan komparatif berupa penidaan pembebanan bunga yang berkesinambungan (perpetual interest effect). ${ }^{7}$

Pemberlakuan UU No. 10/1998 merupakan momen pengembangan perbankan syariah di Indonesia. Undang-undang tersebut membuka kesempatan untuk pengembangan jaringan perbankan syariah, antara lain melalui izin pembukaan Kantor Cabang Syariah (KCS) oleh bank konvensional. ${ }^{8}$

Pada periode UU No. 10/1998 juga dapat dilihat adanya beberapa permasalahan hukum yang masih harus diatur lebih lanjut dan pengaturan tersendiri yang perlu dipertimbangkan dalam regulasi perbankan nasional yang akan datang. Masalah-masalah tersebut antara lain, pertama, bank Islam tunduk pada dua sistem

zaman. Nurul Huda, “Dinamisasi Hukum Islam Versi Mahmud Syaltut," Suhuf, Vol.19, No.1, (Mei, 2007: 25-35), 33.

6 Zainal Said, Polemik Undang-Undang Perbankan Indonesia: Tinjauan Sosio Yuridis (Yokyakarta: The Phinisi Press Yokyakarta, 2016), 1.

7 Wirdyaningsih, et.al, Bank dan Asuransi Islam di Indonesia (Jakarta: Kencana Prenada Mulia 2005), 54.

8 Ibid., 56. 
hukum yang berbeda. Kedua, eksistensi Dewan Pengawas Syariah (DPS). Ketiga, pengawasan bank Islam masih berdasarkan pendekatan konvensional. Keempat, bank sentral memakai standar interest. Kelima, belum memadainya peraturan pelaksanaan bank Islam. Keenam, hukum perdata tetap menjadi acuan dalam dokumentasi dan legitimasi. ${ }^{9}$

Meskipun Piagam Jakarta yang memberi status konstitusional pada syariat, tidak diakomodasi oleh pemerintah Seoharto sebagai bagian dari Undang-undang Dasar 1945, beberapa aspek yang berkenaan dengan syariat telah dilegislasikan dalam sistem hukum nasional. Paling sedikit ada lima aturan hukum yang secara kuat dipengaruhi oleh syariat, telah dilegislasikan dalam hukum positif di masa Soeharto, yaitu Undang-undang Perkawinan, Peraturan Wakaf, Peradilan Agama, Hukum yang membolehkan beroperasinya perbankan Islam, dan Kompilasi hukum Islam yang terkait dengan kodifikasi hukum keluarga dalam Islam, termasuk aturan waris. Semasa pemerintahan presiden Habibie (1998-1999), ada tambahan dua Undang-undang yang mencakup penyelenggaraan haji dan pengelolaan zakat. ${ }^{10}$

Pasca reformasi, UU No. 3/2006 tentang Perubahan UU No. 7/1989 tentang Peradilan Agama, terdapat beberapa perubahan yang memperluas kewenangan Pengadilan Agama dalam menyelesaikan sengketa di bidang pengelolaan zakat dan sengketa di bidang ekonomi syariah. Selain itu juga terdapat undang-undang lain seperti UU No. 38/1999 tentang Pengelolaan Zakat, UU No. 41/2004 tentang Wakaf, UU No. 13/2008 perubahan atas UU No. 17/1999 tentang Penyelenggaraan Ibadah Haji, UU No. 21/2008 tentang Perbankan Syariah. ${ }^{11}$

Berkaitan dengan bank Islam tunduk pada dua sistem hukum yang berbeda, dibutuhkan undang-undang khusus yang mengatur tentang kemandirian keberadaan perbankan syariah di Indonesia. Apalagi pada periode UU No. 10/1998, eksitensi atau operasional perbankan syariah itu masih berpatokan dengan fatwa Majelis Ulama

${ }^{9}$ Wirdyaningsih, et.al, Ibid., 56.

${ }^{10}$ Labib Muttaqin, "Positifisasi Hukum Islam dan Formalisasi Syariah di Tinjau dari Teori Otoritarianisme Khaled Abou El-Fadl", Al-Ihkam, Hukum dan Pranata Sosial, Vol.11, No. 1 (Juni, 2016), 80.

11 Ibid. 
Indonesia (MUI). Jika keberadaan operasional bank syariah berdasarkan pada fatwa MUI, berarti belum memiliki landasan yuridis yang sangat kuat, sebab fatwa MUI itu sendiri tidak mengikat.

Lebih tegasnya bahwa fatwa MUI dalam sistem perundangundangan di Indonesia tidak memiliki kekuatan hukum yang mengikat, sebab tidak dibuat oleh lembaga negara yang berwenang untuk membuat peraturan, namun hanya dibuat oleh lembaga sosial kemasyarakatan, sehingga secara formil hanya berlaku sebagai himbauan moral yang sifatnya tidak mengikat. Fatwa MUI di bidang ekonomi syariah dan keuangan dapat berlaku sebagai hukum formil yang mengikat apabila telah ditetapkan dalam peraturan perundangundangan, sebagaimana ditunjuk oleh UU No. 10/2004 Pasal 7 ayat 4 bahwa "Jenis peraturan perundang-undangan lain selain sebagaimana dimaksud pada ayat 1, diakui keberadaan dan mempunyai kekuatan hukum mengikat sepanjang diperintahkan oleh peraturan perundang-undangan yang lebih tinggi".12

Mengingat dengan asas lex superior derogat legi inferiori (undang-undang yang lebih tinggi dapat mengalahkan yang lebih rendah) kaitannya dengan UU No. 10/2004 tentang Tata Susunan Peraturan Perundang-undangan dapat dipertajam dengan susunan peraturan perundang-undangan yang ada. Catatan yang diberikan oleh Maria faridah Indrati yang pendapatnya juga sejalan dengan pemikiran A. Hamid S. Attamimi mengenai istilah "tata urutan" sebaiknya diganti dengan "tata susunan". Istilah pertama tidak mencerminkan suatu tingkatan atau jenjang (hierarkhi) dari peraturan perundang-undangan yang mengandung fungsi, materi, dan jenis yang berbeda. ${ }^{13}$ Hal ini dikemukakan agar tidak keliru dalam memahami istilah tata susunan peraturan perundang-undangan.

UU No. 10/2004 tentang Tata Susunan Peraturan Perundangundangan adalah; (1) UUD 1945; (2) Undang-Undang; (3) Peraturan Pemerintah Pengganti Undang-Undang (Perpu); (4) Peraturan Pemerintah; (5) Peraturan daerah (Perda). Sesuai dengan UU No. 10/2004, ditemukan bahwa fatwa MUI tidak termasuk dalam tata susunan peraturan perundang-undangan di Indonesia.

12 Rahman Ambo Masse, Figh dan Keuangan Syariah: Antara Realitas dan Kontekstual (Yokyakarta: TrustMedia Publising, 2015), 40.

13 Darji Darmodiharjo, et.al, Pokok-Pokok Filsafat Hukum, Apa dan Bagaimana Filsafat Hukum Indonesia (Jakarta: Gramedia Pustaka Utama, 2006), 226. 
Analisis asas lex superior derogat legi inferiori, maka fatwa MUI sebagai dasar operasional perbankan syariah bukan merupakan sumber hukum formil, tetapi sebagai sumber hukum tidak tertulis (living law). Konteks pelaksanaan hukum yang bersifat mengikat dan berkekuatan hukum tetap adalah berlandaskan dengan tata susunan perundang-undangan dalam UU No. 10/2004. Selain itu, MUI yang memiliki kewenangan untuk mengeluarkan fatwa, namun tidak memiliki kewenangan untuk mengeluarkan undang-undang. Itu sebabnya fatwa MUI sebagai sumber hukum masih sangat lemah daya berlakunya, sehingga belum cukup untuk dijadikan dasar hukum dalam pelaksanaan atau operasional perbankan syariah.

Meskipun MUI hanya memiliki kewenangan melahirkan fatwa, tidak memiliki kewenangan untuk membuat undang-undang, namun kewenangannya membuat fatwa menjadi cikal bakal lahirnya UU No. 21/2008 tentang Perbankan Syariah. Hal itu ditandai dengan fatwa DSN-MUI misalnya; DSN-MUI No.7/DSN-MUI/IV/2000 tentang Mudharabah, DSN-MUI No.8/DSN-MUI/IV/2000 tentang Musyarakah dan seterusnya. Titik fokus dalam seluruh fatwa itu, tidak lain adalah peningkatan kesejahteraan masyarakat dalam bidang investasi memerlukan jasa perbankan syariah yang berdasarkan hukum Islam.

Implementasi ajaran-ajaran Islam melalui fatwa DSN-MUI itu dalam ranah publik dapat terlihat pada lembaga keuangan Syariah. Dasar hukum pelaksanaan lembaga keuangan syariah, khususnya perbankan syariah diatur dalam UU No. 7/1992 tentang Perbankan, kemudian diubah dengan UU No. 10/1998 tentang Bank Indonesia sebagaimana diubah lagi dalam UU No. 23/2004. Adanya payung hukum ini memperjelas sistem operasional perbankan syariah, yaitu hukum Islam. Kemudian dipertegas dengan lahirnya UU No. 21/2008 tentang Perbankan Syariah. Payung hukum itu telah mendorong penguatan eksistensi perbankan syariah di Indonesia. ${ }^{14}$

DSN MUI hanya bersifat himbauan dan tidak memiliki kekuatan hukum mengikat perspektif negara. ${ }^{15}$ DSN merupakan

\footnotetext{
14 Rahman Ambo Masse, 48-49.

${ }^{15}$ Disfa Lidian Handayani, "Hukum Ekonomi Syariah:Tantangan dan Peluang dalam Pengembangan Inovasi Instrumen Keuangan Syariah", Al-Manahij, Jurnal Kajian Hukum Islam, Vol. IX, No.2, (Desember,2015), 341.
} 
bagian dari MUI, yang bukan badan pemerintah namun memiliki otoritas dalam mengeluarkan fatwa terkait dengan masalah perbankan syariah. Dengan lahirnya, UU No. 21/2008 tentang Perbankan Syariah, maka diadakan Komite Perbankan Syariah yang menjadi lembaga yang memformulasikan fatwa DSN ke dalam PBI. ${ }^{16}$

Pertumbuhan perbankan syariah yang semakin pesat mendapat sambutan yang cukup hangat di masyarakat, juga tidak lepas dari dukungan pemerintah, para ulama, dan regulasi BI yang terus mengakomodasi kebutuhan regulasi industri dan membuka kesempatan yang lebih luas kepada perbankan dan investor untuk menjalankan kegiatan usaha Bank Syariah. Komitmen yang tinggi dari BI dalam menyusun peraturan bagi Perbankan Syariah ini bertujuan untuk mewujudkan pertumbuhan Bank Syariah yang sehat dan patuh kepada prinsip syariah. Bank Syariah yang didirikan atau menjalankan kegiatan usahanya mulai/2008, sudah tentu berdasarkan UU No. 21/2008 dan seluruh peraturan pelaksanaannya. Ketentuan-ketentuan yang diatur berdasarkan UU No. 10/1998 dan peraturan pelaksanaannya tetap berlaku sepanjang tidak bertentangan dengan ketentuan UU No. 21/2008.17

Kenyataan bahwa kedudukan Bank Muamalat setelah UU No. 21/2008 dinyatakan berlaku, menunjukkan sebagai salah satu perbankan syariah di Kota Parepare dengan leluasa mengembangkan segala jenis produknya. Selain itu, keberhasilan Bank Muamalat dalam memacu peningkatan jumlah nasabahnya, tidak terlepas dengan kerja keras para pegawainya dalam mempromosikan jenisjenis produknya. Saat ini Bank Muamalat Kota Parepare telah menjadi mitra dengan pengelolaan Biaya Operasional Jurusan Syariah dan Ekonomi Islam STAIN Parepare dalam bentuk produk wadiah. Produk lainnya yang tidak kalah menarik dalam masyarakat adalah produk deposita haji dan umrah, mudharabah, musyarakah, istisnah, asuransi syariah, dan produk-produk lainnya. ${ }^{18}$

16 Luqman Nurhisam, "Kepatuhan Syariah (Sharia Complience) dalam Industri Keuangan Syariah", Ar-Raniry, International Journal Of Islamic Studies, Vol.3, No. 1, (June, 2016), 37.

17 Suryani, "Analisis Faktor Kualitas Pelayanan di Bank Syariah", Al-Iqtishad, Journal of Islamic Economics, Vol. 6, No. 2 (Juli, 2015), 358-359.

18Wardah Bahtiar, Wawancara, di Bank Muamalat Parepare dilakukan pada tanggal 26 Oktober 2015. 
Dikemukakan bahwa acapkali hukum yang telah dikodifikasi dalam suatu undang-undang yang kemudian berlaku sebagai hukum positif terdapat konflik norma (conflict of norms) atau pertentangan dengan undang-undang yang lain. Fungsi asas hukum dalam hukum dapat mengesahkan dan mempunyai pengaruh yang normatif dan mengikat para pihak. Bersifat mengikat karena mendasarkan eksistensinya para rumusan oleh pembentuk undang-undang dan hakim. ${ }^{19}$

Ada beberapa prinsip yang harus diperhatikan dalam asas lex specialis derogat legi generalis, pertama, ketentuan-ketentuan yang didapati dalam aturan hukum umum tetap berlaku, kecuali yang diatur khusus dalam aturan hukum khusus. Kedua, ketentuanketentuan lex specialis harus sederajat dengan ketentuan-ketentuan lex generalis (undang-undang dengan undang-undang). Ketiga, kententuan-ketentuan lex specialis harus berada dalam lingkungan hukum (rezim) yang sama dengan lex generalis. ${ }^{20}$

Penerapan asas lex specialis derogat legi generalis dalam UU No. 21/2008 tentang Perbankan Syariah menentukan kedudukan perbankan syariah secara khusus dari sejumlah peraturan perundangundangan tentang perbankan yang berlaku secara umum. Melalui asas itu menegaskan perbankan syariah memiliki daya saing yang kuat daripada operasional bank-bank konvensional. Legalitas sistem bagi hasil tanpa bunga yang diterapkan dalam perbankan syariah telah diakui dengan memberikan daya tarik tersendiri kepada nasabah dibandingkan dengan bank yang menerapkan sistem bunga. Meskipun undang-undang yang berkaitan dengan perbankan sebelumnya, masih tetap dianggap berlaku pada perbankan syariah. Akan tetapi, dengan berlakunya UU No. 21/2008 semakin mengokohkan dan memberi keleluasaan perbankan syariah dalam menjalankan segala macam aktivitas dan produk-produknya.

Dalam konteks asas lex specialis derogat legi generalis bahwa undang-undang yang lebih khusus dapat mengalahkan undangundang yang lebih umum. UU No. 23/2004 tentang Bank Indonesia perubahan atas UU No. 10/1998 sebagai perubahan atas UU No. 7/1992 tentang Perbankan adalah peraturan perundang-undangan

\footnotetext{
19 Zainal Asikin, Ilmu Hukum (Jakarta: PT. RajaGrafindo, 2015), 110-112.
}

20 Ibid., 112. 
yang berlaku secara umum, sementara UU No. 21/2008 tentang Perbankan Syariah berlaku secara khusus. Apabila dikaitkan dengan asas lex specialis derogat legi generalis berarti UU No. 21/2008 tentang Perbankan Syariah memiliki kedudukan lebih kuat dibandingkan UU No. 23/2004 perubahan atas UU No. 10/1998 yang berlaku umum.

\section{Prosedur Penyelesaian Sengketa Perbankan Syariah Penyelesaian sengketa Perbankan Syariah melalui Arbitrase}

Mekanisme penyelesaian sengketa syariah yang bersifat perdata secara umum dapat diselesaikan melalui 3 (tiga) alternatif. Pertama, ditempuh melalui perdamaian atau yang dikenal dengan sistem ADR (Alternative Dispute Resolution). Kedua, melalui lembaga arbitrase syariah. Ketiga, melalui jalur litigasi (proses peradilan agama). Penyelesaian sengketa bisnis melalui mekanisme ADR dalam bentuk konsultasi, negosisasi, mediasi, konsiliasi, dan penilaian ahli atau melalui mekanisme arbiterase, banyak dipilih oleh para pihak berselisih karena beberapa alasan, diantaranya; kesukarelaan dalam proses, prosedur cepat rahasia (confidential), hemat waktu, hemat biaya, keputusan nonyudisial, fleksibel dalam merancang syaratsyarat penyelesaian sengketa, win-win solution, tetap terpeliharanya hubungan baik antara pihak yang bersengketa. Para Arbiter adalah orang-orang yang memiliki keahlian (expertise) dan putusan arbitrase bersifat final serta mengikat para pihak. Selain itu tidak ada kemungkinan banding dan kasasi terhadap putusan arbitrase. Badan Arbitrase Syariah (Basyarnas) sebagai alternatif penyelesaian sengketa di lembaga keuangan syariah mempunyai tujuan berikut; (a) memberikan penyelesaian yang adil dan cepat dalam sengketasengketa muamalat/perdata yang timbul dalam bidang perdagangan, industri, keuangan, jasa, dan lain-lain. (b) menerima permintaan yang diajukan, oleh para pihak dalam suatu perjanjian, tanpa adanya suatu sengketa untuk memberikan suatu pendapat yang mengikat mengenai suatu persoalan berkenaan perjanjian tersebut. ${ }^{21}$

Namun bila kemacetan tersebut akibat kelalaian, pelanggaran atau kecurangan dari nasabah, maka dapat meminta agar nasabah

${ }^{21}$ Mardani, Hukum Acara Perdata Peradilan Agama dan Mahkamah Syariah (Jakarta: Sinar Grafika, 2009), 74-75. 
menyelesaikan segera. Bila penyelesaian di luar pengadilan tidak dapat dicapai, maka dapat menempuh jalur hukum. Dalam hal ini ada dua cara yang dapat ditempuh, yaitu Pengadilan Negeri atau badan arbitrase. 22

Penyelesaian sengketa perbankan syariah dapat ditempuh dua cara yaitu, Pengadilan Negeri dan badan arbitrase jika merujuk kepada UU No. 30/1999. Namun setelah berlaku UU No. 21/2008 Pasal 55 sangat jelas disebutkan bahwa pengadilan yang berwenang menyelasaikan sengketa perbankan syariah adalah Pengadilan Agama (Religius Court in Indonesia) atau Islamic Court in Indonesia Order. ${ }^{23}$ Dengan begitu, UU No. 21/2008 merupakan pengkhususan dari UU No.30/1999, sehingga pengadilan negeri harus dibaca Pengadilan Agama.

Berlakunya UU No. 3/2006 tentang Peradilan Agama menjamin eksistensi Basyarnas sebagai lembaga penyelesaian sengketa ekonomi syariah di luar pengadilan (nonlitigasi). Adapun yang dimaksud ekonomi syariah sesuai dengan penjelasan undangundang tersebut adalah kegiatan usaha yang dilaksanakan menurut prinsip syariah, meliputi bank syariah, lembaga keuangan syariah, asuransi syariah, reasuransi syariah, dan sebagainya. Sedangkan dalam UU No. 30/1999 tentang Arbitrase dan Alternatif Penyelesaian Sengketa adalah cara penyelesaian sengketa perdata di luar peradilan umum, sedangkan lembaga arbitrase adalah badan yang dipilih oleh para pihak yang bersengketa untuk memberikan putusan mengenai sengketa tertentu. Basyarnas adalah lembaga arbitrase sebagaimana yang dimaksud dalam UU No. 30/1999.24

Mengenai kewenangan lingkungan peradilan agama dalam melaksanakan putusan arbitrase syariah tersebut kini masih ada pihak yang mempertanyakan. Bahkan di kalangan petinggi Mahkamah Agung sendiri sebelum lahirnya Surat Edaran Mahkamah Agung (SEMA) No. 08/2008 sempat terjadi silang pendapat tentang

\footnotetext{
22 Shobirin, "Penyelesaian Pembiayaan Murabahah Bermasalah Di Baitul Maal Wa Tamwil (BMT)", Iqtishadia, Jurnal Kajian Ekonomi Dan Bisnis Islam, Vol. 9, No. 2 (Juli, 2016), 410.

${ }^{23}$ Lina Kushidayati, "The Development of Islamic Law In Indonesia”, Qijis, Qudus International Journal Of Islamic Studies, Vol.1, Number 2 (July-December, 2013), 170.

${ }^{24}$ Frans Hendra Winarta, Hukum Penyelesaian Sengketa Arbitrase Nasional Indonesia dan Internasional (Jakarta: Sinar Grafika Offset, 2012), 145-147.
} 
pengadilan mana sesungguhnya yang berwenang memerintahkan pelaksanaan putusan arbitrase syariah, jika para pihak ternyata tidak mau melaksanakan secara sukarela. Di satu pihak ada yang berpendapat pengadilan agama karena sesuai dengan ketentuan UU No. 3/2006 bahwa pengadilan agama berwenang menangani sengketa ekonomi syariah. Sementara di lain pihak ada yang menyatakan hal itu tetap menjadi kewenangan pengadilan negeri, karena pengadilan agama tidak berwenang menyelesaikan ketentuan UU No. 30/1999. 25

Beberapa ketentuan umum terkait prosedur penyesaian sengketa berdasarkan UU No. 30/1999 sebagai berikut; (a) Pemeriksaan sengketa harus diajukan secara tertulis, dapat juga secara lisan apabila disetujui para pihak dan dianggap perlu oleh Arbiter atau majelis arbiter. (b) Arbiter atau majelis arbiter terlebih dahulu mengusahakan perdamaian antara pihak yang bersengketa. (c) Pemerikasaan atas sengketa harus diselesaikan dalam waktu paling lama 180 hari sejak arbiter atau majelis arbiter terbentuk, namun dapat diperpanjang apabila diperlukan dan disetujui para pihak. (d) Putusan arbitrase harus memuat kepada keputusan yang berbunyi "demi keadilan berdasarkan Ketuhanan Yang Maha Esa" nama singkat sengketa, uraian singkat sengketa, pendirian cara pihak, nama lengkap dan alamat Arbiter, pertimbangan dan kesimpulan Arbiter atau Majelis Arbiter mengenai keseluruhan sengketa, pendapat masing-masing Arbiter dalam hal terdapat perbedaan pendapat majlis arbiter. (e) Dalam putusan ditetapkan suatu jangka waktu putusan harus dilaksanakan. (f) Apabila pemeriksaan sengketa telah selesai, pemeriksaan harus ditutup dan ditetapkan hari sidang untuk mengucapkan putusan arbitrase dan diucapkan dalam waktu paling lama 30 (tiga puluh) hari setelah pemeriksaan ditutup. (g) Dalam waktu paling lama 14 (empat belas) hari setelah putusan diterima, para pihak dapat mengajukan permohonan kepada Arbiter atau majlis arbiter untuk melakukan koreksi terhadap kekeliruan administratif atau menambah atau mengurangi sesuatu tuntutan putusan. 26

\footnotetext{
${ }^{25}$ Cik Basir, Penyelesaian sengketa Perbankan Syariah di Pengadilan Agama dan Mahkamah Syariah (Jakarta: Kencana, 2009), 36 .

${ }^{26}$ Mardani, Hukum Acara Perdata Peradilan Agama dan Mahkamah Syariah, 147-149.
} 
Penyelesaian sengketa perbankan syariah, jika dalam akad disebutkan klausula arbitrase, maka yang berwenang penyelesaian sengketa itu adalah Basyarnas berdasarkan dengan UU No. 30/1999 dan juga UU No. 21/2008. Sebaliknya jika dalam akad tidak disebutkan klausula arbitrase maka yang berwenang menyelesaikan sengketa itu adalah pengadilan agama.

\section{Penyelesaian sengketa Perbankan Syariah melalui Peradilan Agama}

Peradilan adalah salah satu institusi negara dalam memenuhi hajat hidup anggota masyarakat untuk menegakkan hukum dan keadilan. pengadilan agama memiliki kewenangan absolut yang berbeda dengan badan peradilan lainnya, yakni kewenangan dalam bidang perkawinan, bidang kewarisan, wasiat dan hibah, wakaf, sedekah, dan ekonomi syariah berdasarkan UU No. 3/2006 yakni UU tentang Perubahan atas UU No. 7/1989 tentang peradilan agama, dinyatakan bahwa peradilan agama mendapatkan tambahan kewenangan dalam bidang ekonomi syariah. ${ }^{27}$ Oleh karena itu, segala syarat yang harus dipenuhi para hakim, harus disesuaikan dengan tugas-tugas yang diemban peradilan agama. Peradilan agama harus diarahkan menjadi lembaga preventif bagi kemungkinan timbulnya pertikaian yang akan menjurus kepada sengketa ekonomi. ${ }^{28}$

Hakim pengadilan agama memiliki tugas mulia dengan melaksanakan dan menunaikan hukum Allah, yaitu memberikan hak kepada yang patut secara syar'i untuk diterimanya, mencegah dalam konteks itu adalah seorang hakim melalui pengadilan berkewajiban mencegah dan memberikan perlindungan hukum bagi masyarakat sehingga the rule of law dapat dijalankan. Hakim bertugas menghalangi orang untuk berbuat kesewenang-wenangan atau kezaliman pihak-pihak tertentu kepada orang lain. ${ }^{29}$ Lepasnya lembaga peradilan agama dari cengkraman kekuasaan eksekutif

27 Eka Susylawati, Penerapan Asas Personalitas Keislaman dalam Permohonan Pengangkatan Anak di Kab. Pamekasan", Al-Ihkam, Hukum dan Pranata Sosial, Vol.11, No. 2 (Desember, 2016), 412.

28 Busthanul Arifin, Pelembagaan Hukum Islam di Indonesia, Akar Sejarah, Hambatan dan Prospeknya (Jakarta: Gema Insani Press, 1996), 95.

29 Abdul Halim, Peradilan Agama dalam Politik Hukum di Indonesia, dari Otoriter Konservatif menuju Konfigurasi Demokratis-Responsif (Jakarta: PT. Rajarafindo Persada, 2000), 30. 
lewat organisasi, administrasi dan finansial di maksudkan untuk menjadikan hakim benar-benar mandiri tidak terpengaruh oleh kekuasaan eksekutif. 30

Hakim dalam memproses dan memutuskan perkara yang diajukan ke pengadilan tidak boleh bersikap kaku dalam menemukan hukum yang relevan dengan perkara yang dihadapi. Hakim wajib memahami perkara-perkara yang berkembang dalam persidangan agar putusannya dapat diterima dan menjadi sumber dalam penegakkan keadilan. Otoritas dan kemampuan hakim yang dimiliki, khususnya hakim peradilan agama tidak bersifat statis dan destruktif. Akan tetapi, bersifat dinamis dalam menuntut kemampuan, pemahaman tajam dan kapabilitas tidak diragukan. Seorang hakim seharusnya mempunyai kualifikasi tertentu dan syarat-syarat minimal, yaitu memiliki pengetahuan tentang istinbath tathbiqi dan menerapkan produk hukum syar'i yang berasal dari al-Qur'an, sunah, ijma, kiyas, hasil-hasil ijtihad yang relevan dengan masalah yang sedang ditangani dan mengetahui adat kebiasaan masyarakat.

Usaha memperkuat prinsip kekuasaan kehakiman dengan mewujudkan kemandirian lembaga yudikatif, maka sesuai dengan tuntutan reformasi di bidang hukum telah dilakukan beberapa perubahan terhadap UU No. 14/1970 tentang Ketentuan-ketentuan Kekuasaan Pokok Kehakiman, diamandemen dengan UU No. 35/1999. Konsekuensi diundangkannya UU No. 35/1999, diletak kebijakan bahwa segala urusan mengenai peradilan baik yang menyangkut teknis yudisial maupun urusan organisasi, administrasi dan finansial berada satu atap di bawah kekuasaan Mahkamah Agung. Kebijakan itu terkenal istilah kebijakan satu atap (one roof system). 31

Salah seorang hakim pengadilan agama berpendapat bahwa Pengadilan Agama Parepare memiliki peluang yang sangat besar untuk menyelesaikan sengketa bank syariah. Sebab di Kota Parepare dengan keberadaan tiga bank syariah berpotensi akan ada sengketa yang diajukan ke Peradilan Agama Parepare. Sengkata perbankan

30 Ahmad R., "Peradilan Agama di Indonesia," Yudisia, Jurnal Pemikiran Hukum dan Hukum Islam, Vol.6, No.2, (Desember 2015), 337.

31 Jaenal Aripin, Peradilan dalam Bingkai Reformasi Hukum di Indonesia Agama (Jakarta: Kencana, 2008), 9-10. 
syariah merupakan kewenangan mutlak hakim di Pengadilan Agama termasuk Pengadilan Agama Parepare untuk menegakkan atau memberikan kepastian hukum dan keadilan terhadap para pihak yang berperkara. ${ }^{32}$

Dikemukakan bahwa hakim memiliki kemampuan ius curia novit dan rechtvinding tentang sengketa perbankan syariah yang telah menjadi kewenangan mutlak Peradilan Agama berdasarkan dengan UU No. 3/2006. Dengan demikian, hakim itu keliru jika dimohonkan perkara tentang perbankan syariah pasca berlakunya undang-undang tersebut mengatakan belum ada hukum atau undang-undang yang mengatur hal tersebut. ${ }^{33}$ Namun demikian, kemampuan hakim di Pengadilan Agama masih banyak pihak yang meragukan dalam menyelesaikan sengketa ekonomi syariah termasuk sengketa perbankan syariah. Akan tetapi, hakim di Pengadilan Agama menepis keraguan atas kemampuan hakim dalam menyelesaikan sengketa perbankan syariah.

Masalah hakim dan kewajibannya diatur dalam Pasal 28 ayat 1 UU No. 4/2004 tentang Kekuasaan Kehakiman sebagai amandemen dari UU No.1 4/1970. Kemudian UU No. 4/2004 diamandemen lagi dengan UU No. 48/2009 disebutkan dalam Pasal 5 ayat 1 yang berbunyi: "Hakim dan hakim konstitusi wajib menggali, mengikuti dan memahami nilai-nilai hukum dan rasa keadilan yang hidup dalam masyarakat."

Ajaran hukum bebas yang memberikan kebebasan kepada hakim dalam mengambil keputusan, maka tidak benar manakala membatasi kebebasan hakim menemukan hukum dan rasa keadilan yang hidup dalam masyarakat. Hakim dapat menentukan putusan tanpa harus terikat pada undang-undang. Indonesia sebagai negara yang mengikuti ajaran hukum bebas berarti memberikan kebebasan kepada hakim untuk menggali nilai-nilai hukum dan rasa keadilan untuk dijadikan dasar mengambil keputusan.

Supreme of competense yang dialami oleh Peradilan Agama adalah diperolehnya kewenangan baru di bidang ekonomi syariah. Perluasan kewenangan baru yang dimaksud secara ekspelisit

32 Gunawan, Wawancara, Hakim Pengadilan Agama dilakukan pada tanggal 08 Oktober 2015.

${ }^{33}$ Gunawan, Ibid. 
dinyatakan pada Pasal 49 UU No. 3/2006 yakni ekonomi syariah. Penambahan kewenangan baru itu sesuai dengan perkembangan hukum masyarakat, khususnya masyarakat muslim, sebagaimana dinyatakan Eugien Ehrlich bahwa "hukum yang baik adalah hukum yang sesuai dengan hukum yang hidup di masyarakat," teori itu berpangkal pada perbedaan antara hukum positif dengan hukum yang hidup (living law) dalam masyarakat. ${ }^{34}$

Merespon dengan kewenangan Peradilan Agama dalam menjalankan hukum positif yang berkaitan dengan perbankan syariah, dapat dilihat dalam UU No. 21/2008 Pasal 55 ayat 1"Penyelesaian sengketa perbankan syariah dilakukan oleh pengadilan dalam lingkungan peradilan agama." Ayat 2 "Dalam hal para pihak telah memperjanjikan penyelesaian sengketa selain sebagaimana dimaksud pada ayat (1), penyelesaian sengketa dilakukan sesuai dengan isi Akad." Ayat 3 "Penyelesaian sengketa sebagaimana dimaksud pada ayat (2) tidak boleh bertentangan dengan Prinsip Syariah". ${ }^{35}$

Uraian sebelumnya tentang UU No. 30/1999 tidak lain merupakan bagian dari hukum materil yang berlaku di lingkungan Peradilan Umum. Penyelesaian sengketa di bidang ekonomi syariah khususnya bidang perbankan syariah, yang memiliki kewenangan absolut adalah Peradilan Agama. Pengadilan Agama harus menerapkan ketentuan UU No. 30/1999, di samping ketentuanketentuan yang terdapat dalam Pasal 195-208 dan Pasal 224 HIR atau Pasal 206-240 dan Pasal 258 R.Bg yang merupakan dasar dalam melaksanakan eksekusi terhadap putusan. Adapun mengenai katakata "Pengadilan Negeri" yang terdapat dalam UU No. 30/1999 tersebut dengan sendirinya harus dibaca "Pengadilan Agama." 36

Secara teknis harus memerhatikan ketentuan yang terdapat dalam SEMA No. 08/2008, secara khusus mengatur tentang pelaksanaan eksekusi putusan arbitrase syariah oleh Pengadilan Agama adalah;

\footnotetext{
34 Jaenal Aripin, Peradilan dalam Bingkai Reformasi Hukum di Indonesia Agama, 432.

35 Sutan Remy Sjadeini, Perbankan Syariah, Produk-Produk dan Aspek-Aspek Hukumnya (Jakarta: Kencana, 2014),. , 112-113.

${ }^{36}$ Cik Basir, Penyelesaian sengketa Perbankan Syariah di Pengadilan Agama dan Mahkamah Syariah, 113.
} 
1. Putusan Badan Arbitrase Syariah baru dapat dilaksanakan apabila ketentuan dalam Pasal 59 UU No. 30/1999 telah dipenuhi, yaitu; (a) dalam waktu paling lama 30 (tiga puluh) hari terhitung sejak tanggal putusan Badan Arbitrase Syariah diucapkan, lembar asli atau salinan autentik putusan diserahkan dan didaftarkan oleh arbiter kepada panitera pengadilan agama. (b) penyerahan dan pendaftaran dilakukan dengan pencatatan dan penandatanganan pada bagian akhir atau di pinggir putusan oleh panitera pengadilan agama. (c) arbiter atau kuasanya wajib menyerahkan putusan, salinan atau autentiknya kepada panitera pengadilan aama. (d) tidak dipenuhi ketentuan sebagaimana dimaksud dalam huruf a di atas, berakibat putusan arbitrase tidak dapat dilaksanakan. (e) Semua biaya yang berhubungan dengan pembuatan akta pendaftaran dibebankan kepada para pihak.

2. Perintah melaksanakan putusan Badan Arbitrase Syariah tersebut diberikan dalam waktu paling lama 30 (tiga puluh) hari setelah permohonan eksekusi didaftarkan kepada panitera Pengadilan Agama.

3. Ketua Pengadilan Agama sebelum melakukan perintah pelaksanaan, memeriksa terlebih dahulu apakah;

a. Persetujuan untuk menyelesaikan sengketa melalui Badan Arbitrase Syariah dimuat dalam suatu dokumen yang ditandatangani oleh para pihak.

b. Sengketa yang diselesaikan tersebut adalah sengketa di bidang ekonomi syariah dan mengenai hak yang menurut hukum dan peraturan perundang-undangan dikuasai sepenuhnya oleh pihak yang bersengketa.

c. Putusan Badan Arbitrase Syariah tidak bertentangan dengan prinsip syariah.

d. Ketua Pengadilan Agama tidak memeriksa alasan atau pertimbangan dari putusan Badan Arbitrase Syariah.

e. Perintah Ketua Pengadilan Agama ditulis pada lembar asli atau salinan autentik putusan Badan Arbitrase Syariah yang dikeluarkan.

f. Putusan Badan Arbitrase Syariah yang telah dibubuhi perintah Ketua Pengadilan Agama dilaksanakan sesuai 
dengan ketentuan pelaksanaan putusan yang telah mempunyai kekuatan putusan tetap. ${ }^{37}$

Putusan Badan Arbitrase Syariah (BAS) belum dapat dikatakan mengikat dan belum berkekuatan hukum tetap, sepanjang putusan tersebut belum didaftarkan ke panitera pengadilan agama dalam waktu paling lama 30 (tiga puluh) ha

\section{Penutup}

Asas lex specialis derogat legi generalis menempatkan UU No. 23/2004 tentang Bank Indonesia perubahan atas UU No. 10/1998 sebagai perubahan atas UU No. 7/1992 tentang Perbankan adalah undang-undang yang berlaku secara umum. Sementara UU No. 21/2008 tentang Perbankan Syariah berlaku secara khusus. Penerapan asas lex specialis derogat legi generalis berarti UU No. 21/2008 tentang Perbankan Syariah memiliki kedudukan lebih kuat dibandingkan UU No. 23/2004 sebagai perubahan atas UU No. 10/1998 yang berlaku umum. keberlakuan UU No. 21/2008 mengokohkan dan memberi keleluasaan perbankan syariah untuk menjalankan segala ragam aktivitas dan produk-produknya.

Penyelesaian sengketa perbankan syariah dapat ditempuh dua cara yaitu, pengadilan negeri dan badan arbitrase jika merujuk kepada UU No. 30/1999. Setelah berlaku UU No. 21/2008 Pasal 55 bahwa pengadilan yang berwenang menyelesaikan sengketa perbankan syariah adalah pengadilan agama. UU No. 21/2008 merupakan pengkhususan atau pengecualian dari UU No. 30/1999, sehingga pengadilan negeri harus dibaca pengadilan agama. Putusan Badan Arbitrase Syariah tidak mengikat atau tidak mempunyai kekuatan hukum tetap, sepanjang putusannya belum didaftarkan ke panitera pengadilan agama dalam waktu paling lama 30 (tiga puluh) ha Putusan Badan Arbitrase Syariah meskipun dianggap praktis dalam menyelesaikan sengketa perbankan syariah, tetap saja dilakukan upaya hukum ke pengadilan agama yang wilayah hukumnya meliputi wilayah termohon untuk mendapatkan kekuatan hukum tetap agar putusan dapat dijalankan oleh para pihak yang

\footnotetext{
37 Cik Basir, Penyelesaian sengketa Perbankan Syariah di Pengadilan Agama dan Mahkamah
} Syariah, 144-115. 
bersengketa. Putusan Badan Arbitrase Syariah (BAS) agar mendapatkan pengesahan dari pengadilan agama.

\section{Daftar Pustaka}

Arifin, Busthanul. Pelembagaan Hukum Islam di Indonesia, Akar Sejarah, Hambatan dan Prospeknya. Jakarta: Gema Insani Press, 1996.

Aripin, Jaenal. Peradilan dalam Bingkai Reformasi Hukum di Indonesia Agama. Jakarta: Kencana, 2008.

Asikin, Zainal. Ilmu Hukum. Jakarta: PT. RajaGrafindo, 2015.

Bahtiar, Wardah. Wawancara. Di Bank Muamalat Parepare dilakukan pada tanggal 26 Oktober 2015.

Basir, Cik. Penyelesaian sengketa Perbankan Syariah di Pengadilan Agama dan Mahkamah Syariah. Jakarta: Kencana, 2009.

Darmodiharjo, Darji. et.al,. Pokok-Pokok Filsafat Hukum, Apa dan Bagaimana Filsafat Hukum Indonesia. Jakarta: Gramedia Pustaka Utama, 2006.

Gunawan. Wawancara, Hakim Pengadilan Agama dilakukan pada tanggal 08 Oktober 2015.

Halim, Abdul. Peradilan Agama dalam Politik Hukum di Indonesia, dari Otoriter Konservatif menuju Konfigurasi Demokratis-Responsif. Jakarta: PT. Rajarafindo Persada, 2000.

Handayani, Disfa Lidian. "Hukum Ekonomi Syariah:Tantangan dan Peluang dalam Pengembangan Inovasi Instrumen Keuangan Syariah". Al-Manahij, Jurnal Kajian Hukum Islam, Vol. IX, nomor 2, (Desember,2015).

Huda, Nurul. "Dinamisasi Hukum Islam Versi Mahmud Syaltut". Suhuf, Vol.19, nomor 1, (Mei, 2007: 25-35).

Iswanto, Bambang. "Peran Bank Indonesia, Dewan Syariah Nasional, Badan Wakaf Indonesia dan Baznas dalam Pengembangan Produk Hukum Ekonomi Islam di Indonesia". Iqtishadia, Jurnal Kajian Ekonomi Dan Bisnis Islam, volume 9, nomor 2 (Juli, 2016).

Khasanah, Karimah. "Hukum Ekonomi Syariah, Indeks Pembangunan Manusia dan Kapitalisme Global". Al-Manahij, Jurnal Kajian Hukum Islam, Vol. IX, nomor 2, (Desember, 2015).

Kushidayati, Lina. "The Development of Islamic Law In Indonesia". Qijis,Qudus International Journal Of Islamic Studies, Vol.1, number 2 (July-December, 2013). 
Mardani. Hukum Acara Perdata Peradilan Agama dan Mahkamah Syariah. Jakarta: Sinar Grafika, 2009.

Masse, Rahman Ambo. Figh dan Keuangan Syariah: Antara Realitas dan Kontekstual. Yokyakarta: TrustMedia Publising, 2015.

Muttaqin, Labib. "Positifisasi Hukum Islam dan Formalisasi Syariah di Tinjau dari Teori Otoritarianisme Khaled Abou El-Fadl", AlIhkam, Hukum dan Pranata Sosial, Vol.11, No. 1, Juni, 2016.

Nurhisam, Luqman."Kepatuhan Syariah (Sharia Complience) dalam Industri Keuangan Syariah". Ar-Raniry, International Journal of Islamic Studies, Vol.3, nomor 1, (June, 2016).

R., Ahmad. "Peradilan Agama di Indonesia". Yudisia, Jurnal Pemikiran Hukum dan Hukum Islam, Vol.6, No.2, (Desember 2015).

Rodliyah, Nunung. "Arbitrase Syariah sebagai Alternatif Penyelesaian Sengketa Lembaga Perbankan Syariah serta Kekuatan dan Kelemahan dalam Penerapan di Indonesia". The $16^{\text {th }}$ Annual Internasional Conference on Islamic Studies, AICIS 2016, IAIN Raden Intan Lampung, November, 2016.

Said, Zainal. Polemik Undang-Undang Perbankan Indonesia: Tinjauan Sosio Yuridis. Yokyakarta: The Phinisi Press Yokyakarta, 2016.

Shobirin. "Penyelesaian Pembiayaan Murabahah Bermasalah Di Baitul Maal Wa Tamwil (BMT)". Iqtishadia, Jurnal Kajian Ekonomi dan Bisnis Islam, volume 9, nomor 2 (Juli, 2016).

Sjadeini, Sutan Remy. Perbankan Syariah, Produk-Produk dan AspekAspek Hukumnya. Jakarta: Kencana, 2014.

Supriadi, Ahmad. "Implementation Of Islamic Economic about Mortgages."Qijis, Qudus International Journal Of Islamic Studies, Vol.1, Issue 2, (Agust, 2014).

Suryani. "Analisis Faktor Kualitas Pelayanan di Bank Syariah". AlIqtishad, Journal of Islamic Economics, volume 6, nomor 2 (Juli, 2015).

Susylawati, Eka. Penerapan Asas Personalitas Keislaman dalam Permohonan Pengangkatan Anak di Kab. Pamekasan". AlIhkam, Hukum dan Pranata Sosial, volume 11, nomor 2 (Desember, 2016).

Winarta, Frans Hendra. Hukum Penyelesaian Sengketa Arbitrase Nasional Indonesia dan Internasional. Jakarta: Sinar Grafika Offset, 2012.

Wirdyaningsih. et.al, Bank dan Asuransi Islam di Indonesia. Jakarta: Kencana Prenada Mulia, 2005. 